\title{
Foreword: facilitating student learning
}

\section{Susan R. Komives}

If asked "Can leadership be taught?" (Parks, 2005), anyone reading this book should shout a resounding "Yes, of course!" and an even louder "Yes" to the profound parallel question "Can leadership be learned?" Yet, in reality, the gap between teaching and learning can seem insurmountable. In this book, Gama Perruci and Sadhana Warty Hall provide essential guidance to "inhabit the gap" between teaching leadership and learning leadership (Komives, 2000).

This book invites leadership educators, including teachers, faculty, student-affairs professionals, industry trainers, and supervisors in any sector - including education, for-profit and nonprofit sectors, and government agencies - to pause, and identify and reflect on their personal philosophy of the teaching and learning process. What do you believe about how teaching matters? How do you think students best learn? What environments and experiences can an educator create to best develop the capacity for leadership in individuals, as well as in groups or teams? What learning and developmental outcomes do you aim to address? How do you apply leadership theory to the practice of practice? And every leadership educator, employer, supervisor, and mentor should ask: "What does your own leadership teach through modeling?"

I retired in 2012. Writing this Foreword was a grand opportunity to reflect on lessons from 45 years in higher education focusing on collegestudent leadership. Some lessons are easy; for instance, every leadership educator must have or must develop a deep and pervasive belief that leadership is both learnable and teachable, and that the way they model leadership is a desirable pedagogical practice.

Some lessons are harder to implement, such as how to design and scaffold meaningful leadership learning experiences. In this book, Perruci and Hall present scaffolding for adding complexity from the study of leadership (education) to include building leadership competencies (training) and ultimately advancing personal leadership growth (development); indeed, they subtitle the book "Bridging Theory and Practice." Scaffolding is hard because it requires that both students and educators have a growth mindset 
(Dweck, 2006), acknowledging they know they can learn leadership concepts and build effective leadership capacities. Developing a growth mindset and the motivation and readiness to dig deep and learn to apply leadership learning is a critical contribution of this book.

I applaud Perruci and Hall for taking a campus-wide approach to teaching and learning leadership. In 2004, when we wrote Learning Reconsidered (NASPA/ACPA, 2004), we reaffirmed that learning was a process that happens across the entirety of the student's experience - their families, jobs, sports teams, classrooms, residence halls, student organizations, friendship groups, religious groups, and service settings. Leadership is happening everywhere a student goes, including in cyberspace and social media. Becoming observers of leadership in action is a crucial step in students' awareness of leadership development.

The goals of learning and developing leadership capacity must include developing students' cognitive complexity, as well as their intrapersonal and interpersonal capacity. Fortunately, models and frameworks exist to guide educators in the design of experiences that promote learning and help educators "inhabit the gap." Baxter Magolda's (2004) Learning Partnership Model provides useful guidance in meeting students where they are, recognizing that they have meaningful experiences, validating them as knowers, and mutually constructing the meaning of new learning that challenges previously held assumptions and beliefs.

I remember a wonderful moment in my leadership classroom at Denison University circa 1975. My co-teacher (an economics faculty member) and I (an associate dean of students) were planning a unit on "power and leadership" for our next class. It was a beautiful spring day, and students clamored that our next class meet outside in a nearby grove of trees, as was often the campus spring tradition. Sharing the organization of content on my overhead transparencies (high tech in those days), I said it just wouldn't be possible; I had to use the overhead projector. Imagine my surprise to arrive to an empty classroom to find a message on the blackboard that said: "We are outside if you'd like to join us!" What a perfect exhibition of power and what a great class discussion jointly making meaning of how they claimed power in the context of the planned lesson!

The leadership development process has to start where students are in their own development, and it needs to attend to the development of two other critical processes addressed in this book: developing leadership self-efficacy and developing a leader identity. Leadership self-efficacy is critical to learning leadership and to engaging in leadership with others. Leadership self-efficacy is explored in this book as a central belief. This belief, in turn, contributes to the student's leader identity. In our leadership identity development research I found it enlightening to realize that 
one's view or philosophy of leadership is in dynamic reciprocity with how one views oneself as a leader (i.e., one's leader identity). If leadership is viewed only as what a person does when in a position of authority (e.g., the president of the organization), meaning only the leader does leadership, then someone does not believe they are a leader unless they have a title. Developing a more complex view or philosophy will expand students' access to seeing themselves as leaders without a title, and facilitators of the process of leadership when engaged with others working toward shared goals, even if not in a position of authority.

As a dean, I remember observing a student government association (SGA) meeting in which a quiet young woman was clearly following the whole discussion and said nothing until right before a key vote was to be taken. She raised her hand and said: "This has been a great discussion but sometimes confusing. Is it accurate that a 'yes' vote on this motion would mean ... [and gave a summary] and a 'no' vote would mean . . . [and gave a summary]?" The group clarified further, summarized, and voted. After the meeting I told her: "That showed great leadership to intervene just at the right time and get the issues clarified. Good for you!" She sat up straighter and said: "I didn't realize that was leadership." I affirmed that she was indeed a good leader. Two years later she actually ran for president of the SGA and won. Once she had some language for leadership she started shifting her perspective of leaders and those doing leadership. She told me some months later that this affirmation contributed to her leadership self-efficacy and enhanced her leader identity.

Reading this book was a wonderful experience to affirm there is now a large body of research on what students should learn about leadership, as well as how students learn leadership. How students learn collaborative, relational leadership is the focus of our Multi-Institutional Study of Leadership (MSL; see leadershipstudy.net), which has over ten years of data studying nearly 500000 students on 400 college campuses in the United States and several other countries. In this book, Perruci and Hall address several of the high-impact practices in MSL findings, including dialogue skills, mentoring, and community service.

This fine book draws from the liberal-arts experiences of the authors and their work at Dartmouth's Rockefeller Center and the McDonough Center at Marietta College to provide a comprehensive understanding of, for, and about leadership. Their years of experience are translated masterfully to examine the teaching role in exploring leadership training, education, and development of leadership students. Their focus on the roles of the leadership educator as teacher, mentor, curriculum designer, and leader peels away layers of complexity to challenge each educator to develop their own philosophy of leadership, understand their personal commitment to 
engaged scholarship, and, above all, commit to personal self-exploration to be aware of themselves as leaders.

Along with Perruci and Hall, I invite you to do the hard work to explore yourself, guide students to explore themselves, and together build an engaged learning environment (in the classroom and beyond) that meets students where they are, validates their growth mindsets and that they are knowers, and mutually makes meaning of how complex human beings can effectively work together in messy situations. This book is your support to try new pedagogies, take risks, and trust learners with exploring messy leadership topics with you and with each other. Leadership learning is a process that lasts a lifetime and, for many, it will start in your classroom.

\section{REFERENCES}

Baxter Magolda, M.B. (2004). Learning Partnerships Model: A Framework for Promoting Self-Authorship. In M.B. Baxter Magolda and P.M. King (Eds.), Learning Partnerships: Theory and Models of Practice to Educate for SelfAuthorship (pp. 37-62). Sterling, VA: Stylus.

Dweck, C.S. (2006). Mindset: The New Psychology of Success. New York: Random House.

Komives, S.R. (2000). Inhabit the Gap. About Campus: Enhancing the Student Learning Experience, 5 (5), 31-2.

NASPA/ACPA. (2004). Learning Reconsidered: A Campus-wide Focus on the Student Experience. Washington, DC: National Association of Student Personnel Administrators and the American College Personnel Association.

Parks, S.D. (2005). Leadership Can Be Taught: A Bold Approach for a Complex World. Boston, MA: Harvard Business School Press. 